\title{
Assessment of pain, acceptance of illness, adjustment to life with cancer and coping strategies in breast cancer patients
}

\author{
Aleksandra Czerw ${ }^{1} \cdot$ Urszula Religioni $^{1} \cdot$ Andrzej Deptała $^{2}$
}

Received: 20 March 2015 / Accepted: 24 May 2015/Published online: 2 June 2015

(c) The Author(s) 2015. This article is published with open access at Springerlink.com

\begin{abstract}
Introduction Breast cancer is the most common malignant neoplasm in women. Over the past 40 years, the number of patients diagnosed with breast cancer quadrupled. Breast cancer is one of the most frequent causes of death in women aged 65 and more in Poland.

Purpose The purpose of the study was to evaluate coping strategies, pain management, disease acceptance and adjustment to cancer in patients diagnosed with breast cancer and to assess the effect of socioeconomic variables on the above mentioned issues.

Methods The study included 193 patients diagnosed with breast cancer during outpatient chemotherapy (classical chemotherapy, hormone therapy, molecularly targeted therapies) at the Center of Oncology, Maria SkłodowskaCurie Institute in Warsaw. We applied the Paper and Pencil Interview (PAPI) technique. The questionnaire interview consisted of demographic questions (socioeconomic variables) and the following four psychometric tests: BPCQ (Beliefs about Pain Control Questionnaire), measuring the influence of factors affecting pain management in patients, CSQ (Coping Strategies Questionnaire), designed to evaluate pain coping strategies, AIS (Acceptance of Illness Scale) questionnaire, measuring disease acceptance, and the mini-MAC (Mental Adjustment to Cancer) scale.
\end{abstract}

Aleksandra Czerw

ola_czerw@wp.pl

1 Public Health Department, Medical University of Warsaw, Warsaw, Poland

2 Division of Cancer Prevention, Department of Oncology and Hematology CSK MSW, Medical University of Warsaw, Warsaw, Poland
Results The results of BPCQ show that breast cancer patients mostly believe that doctors control pain; the mean result for the group was 17.09 and test values were differentiated by education and professional status. The top average score in the pain coping strategies questionnaire was recorded in the positive coping self-statement subscale (mean score $=21.81$ ), whereas the lowest, in the catastrophizing subscale (mean score $=10.60$ ). Here, education and income proved most significant in accounting for the differences recorded. The mean score on the AIS was 28.45, and the key factor differentiating the results was income. As far as the mini-MAC is concerned, we reported the highest score in the fighting spirit subscale (23.43). The average results in the scale were slightly differentiated by socioeconomic variables.

Conclusions Breast cancer patients mostly believe that those who control pain are doctors. Amongst the strategies of coping with pain, the top average score was recorded in the positive coping self-statement subscale. We found out that the level of disease acceptance depends on respondent's income. The higher the income, the greater the acceptance of illness.

Keywords Breast cancer - Pain evaluation - Acceptance of illness - Quality of life

\section{Background}

Breast cancer is the most common malignant neoplasm in women, both in developed and developing countries [1]. Statistically 1 in 12 women suffers from breast cancerwhich is 1 in every 4 cancer patients. Breast cancer is one of the most frequent causes of death in women aged 65 and more in Poland [2]. 
Breast cancer risk factors include age 50 or older, inherited mutation in the BRCA1, BRCA2, ATM, PTEN, TP53, and $C H E C K 2$ genes, having a first-degree relative with breast cancer, early start of menstrual cycles (before age 12), late menopause (after age 55), having first child after age 30, having no children, obesity, animal fat-rich diet, routine consumption of more than two alcoholic beverages per day, long-term (more than 5 years) use of contraceptives and hormone replacement therapy, exposure to ionizing radiation, non-invasive breast cancer [ductal hyperplasia $(\mathrm{DH})$, atypical ductal hyperplasia $(\mathrm{ADH})$, lobular carcinoma in situ (LCIS)] and a history of the following: breast cancer, ovarian cancer, endometrial carcinoma, colorectal cancer [3].

Over the past 40 years in Poland the number of patients diagnosed with breast cancer quadrupled. In 1975, there were more than 4000 new cases. In contrast, in 2012 the same number was just below 17,000. It is estimated that in the next 15 years, the number of newly diagnosed patients will exceed 21,000 and the incidence rate will be only slightly lower than the average breast cancer incidence rate in Europe [2].

When we compare Polish statistical data with those from Europe and the rest of the world, the incidence rate in Poland remains at an average level. For instance, in Great Britain, Denmark, Finland, the United States, or Canada the number is several times higher. What is worrying, though, is that despite higher breast cancer incidence rates in the enumerated countries, the death rate due to the disease is comparable to that in Poland [4].

Cancer, and in particular breast cancer involving mastectomy, is a heavy mental burden for affected women. There are numerous assessment methods providing effective psychological support to breast cancer patients [5-7].

\section{Purpose}

The purpose of the study was to evaluate coping strategies, pain management, disease acceptance, and adjustment to cancer in patients diagnosed with breast cancer. In addition, we also analyzed the effect of socioeconomic variables (education, professional status, income, place of residence) and chemotherapy on the above mentioned issues.

\section{Methods}

The study included 193 patients diagnosed with breast cancer, undergoing outpatient chemotherapy (classical chemotherapy, hormone therapy, molecularly targeted therapies) at the Center of Oncology, Maria SkłodowskaCurie Institute in Warsaw in the year 2013. We applied the
Paper and Pencil Interview (PAPI) technique. The questionnaire interview was composed of demographic questions (socioeconomic variables) and the following four psychometric tests:

1. Beliefs about Pain Control Questionnaire (BPCQ) designed to assess patients in pain.

2. Pain Coping Strategies Questionnaire (CSQ) used to evaluate patients suffering from pain.

3. Acceptance of Illness Scale (AIS), measuring adjustment to disease.

4. Mental Adjustment to Cancer (mini-MAC) scale, measuring the level of mental adjustment to disease.

To analyze the study findings, we applied the ANOVA and Kruskal-Wallis tests. We used the Mann-Whitney $U$ test for the comparison of differences between the study groups. We treated $p$ values less than 0.05 as statistically significant.

Test scores were correlated with socioeconomic characteristics of the respondents: education, professional status, place of residence, net income-per-household-member, and chemotherapy in the past year.

The study was conducted with the approval of the Bioethics Committee at the Medical University of Warsaw on 16 April 2013.

The patients were informed that the study was carried out by the Medical University of Warsaw and familiarized with the study purpose. Each study subject was informed that the results obtained would be used for research purposes only. The study included individuals who gave informed, non-written consent to participate. All individuals included in the study were adults.

\section{Results}

\section{Pain Control}

The statements which form the Beliefs about Pain Control Questionnaire (BPCQ) measure the power of individual beliefs regarding pain management: personally (internal factors), through the effect of doctors (powerful others), and by chance events [8].

The results of BPCQ show that breast cancer patients mostly believe that the greatest role in pain control is played by doctors, with the group mean score of 17.09 and the standard deviation of 4.40. In the case of chance events, the mean score for the patients was 16.27 and the standard deviation was 4.32. The average result for internal factors, in turn, was 16.11 and the standard deviation was 5.28 (Fig. 1).

It turned out that the most crucial factors in pain management in breast cancer patients were education and 


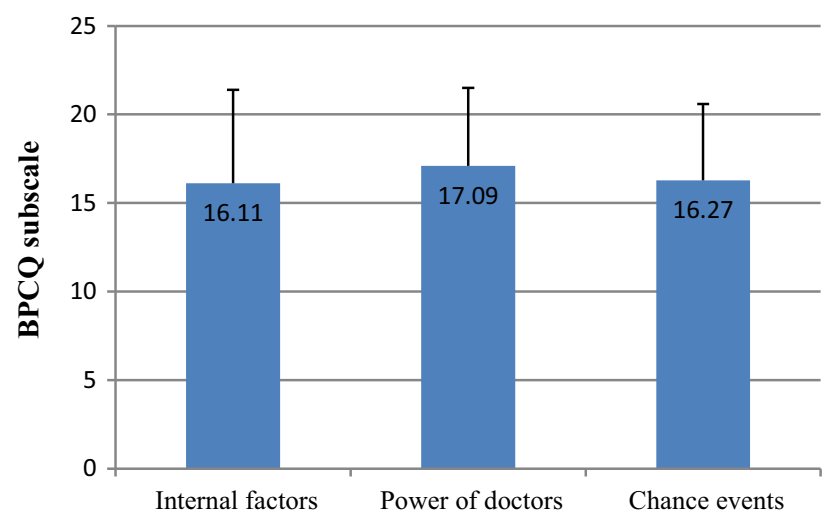

Fig. 1 BPCQ test scores in breast cancer patients

professional status. We observed that the power of doctors clearly decreased as the level of education increased $(p=0.014)$. In participants with vocational education, the mean result in this subscale was 17.81; in high-school graduates it was 17.33 , whereas in respondents with a higher level of education it was only 16.04 (Fig. 2). Furthermore, we observed a negative correlation between the tendency to attribute power to chance events and an increase in the level of education $(p=0.000)$. Respondents of vocational education had a mean score of 18.81; those of high-school education, 16.63; while college graduates, only 14.73. The standard deviation in the case of patients with vocational education was 3.54 , whereas in high-school and college graduates it was only 4.01 and 4.35 , respectively (Fig. 3).

The belief that doctors control pain was further diversified by the professional status of the respondents $(p=0.021)$. Patients who were retired attributed more power to doctors (means test score $=17.77$ ) than did patients at a working age $($ mean $=16.40)$ (Fig. 4).

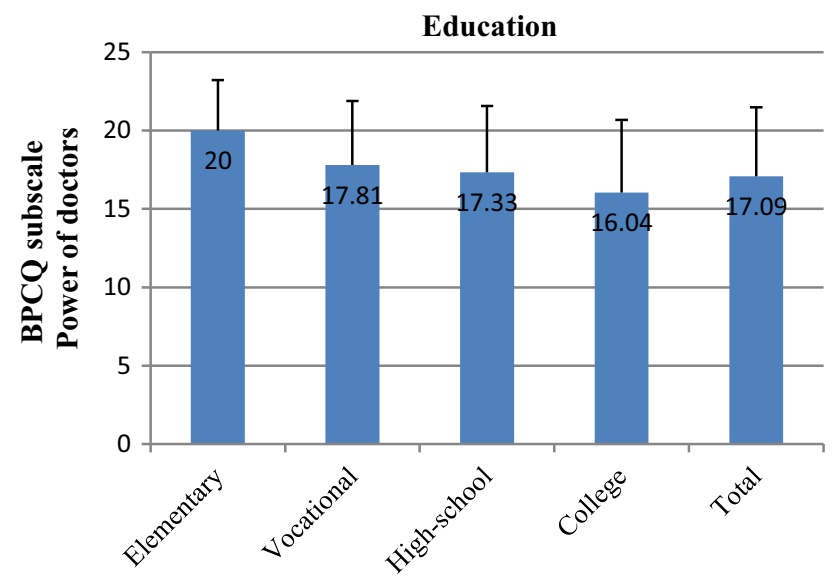

Fig. 2 BPCQ test scores (power of doctors) in breast cancer patients vs education

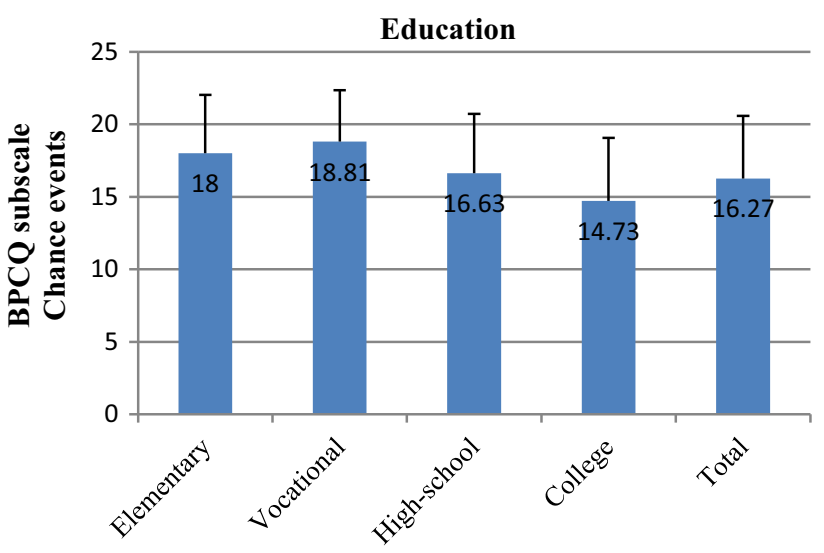

Fig. 3 BPCQ test scores (chance events) in breast cancer patients vs education

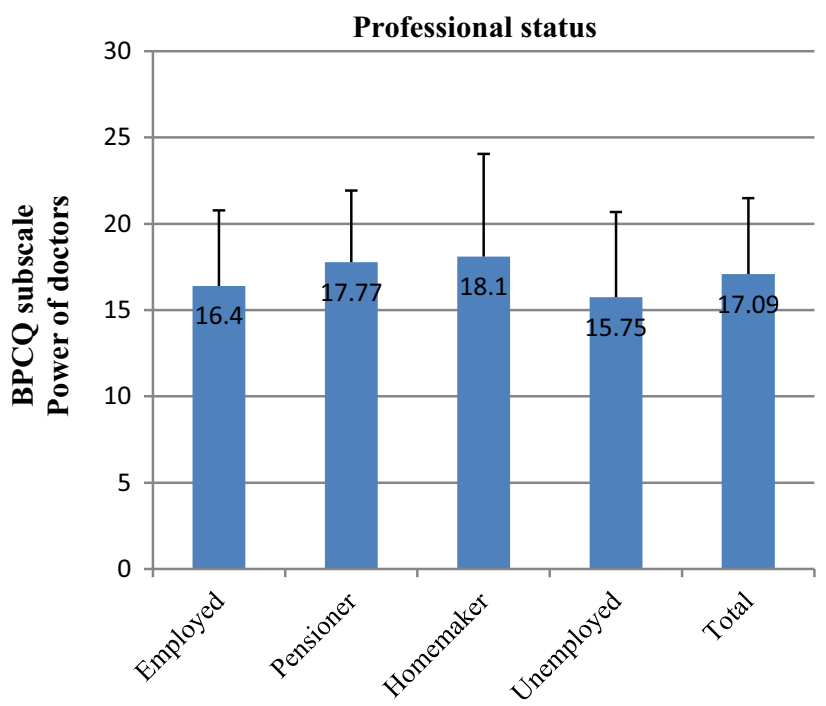

Fig. 4 BPCQ test scores (power of doctors) in breast cancer patients vs professional status

The remaining socioeconomic variables (place of residence, marital status, income) did not significantly differentiate the BPCQ scores.

\section{Strategies of coping with pain}

The Coping Strategies Questionnaire is designed to evaluate patient strategies of coping with pain and to verify their effectiveness in pain reduction or control. Methods of coping with pain reflect six cognitive strategies and one behavioral strategy, which in turn are a part of the following three components: cognitive coping, diverting attention and undertaking replacement activities, catastrophizing and seeking hope $[9,10]$.

We recorded the top average score for breast cancer respondents in the coping self-statement subscale 


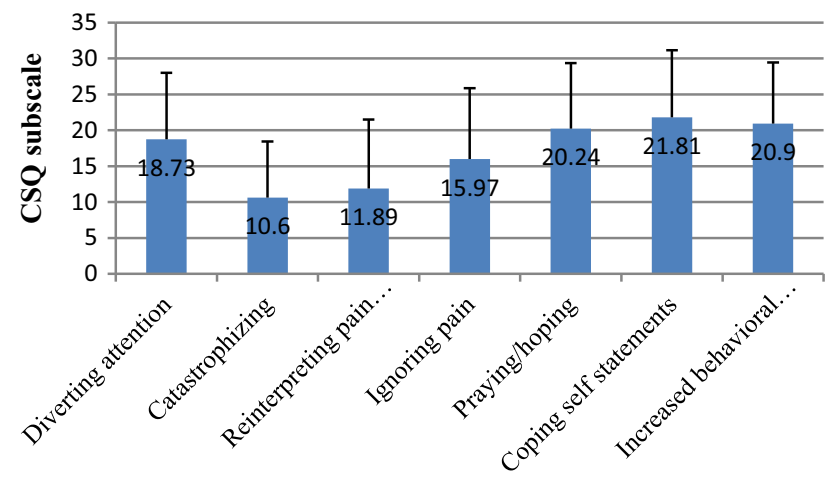

Fig. 5 CSQ scores in breast cancer patients

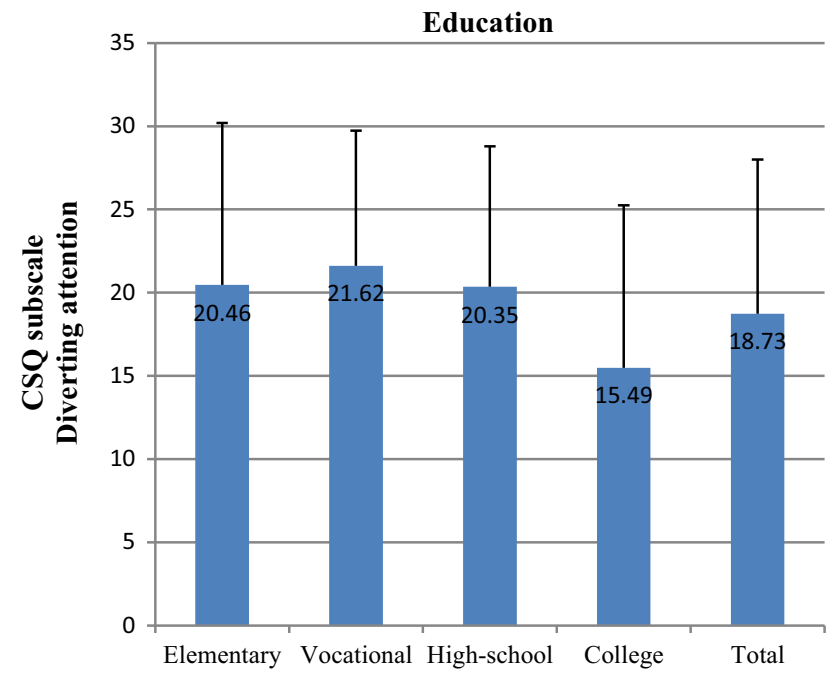

Fig. 6 CSQ scores (diverting attention) in breast cancer patients vs education

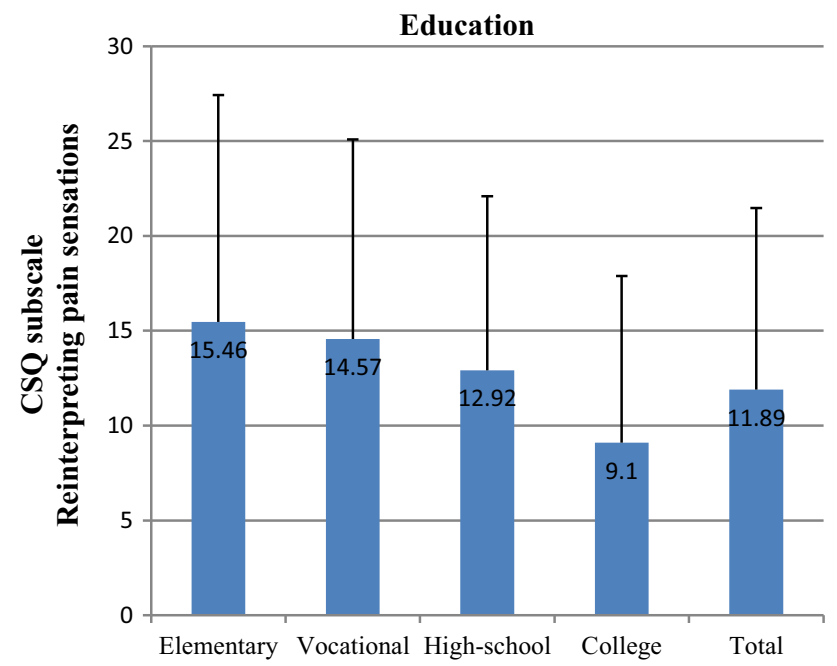

Fig. 7 CSQ scores (reinterpreting pain sensations) in breast cancer patients vs education

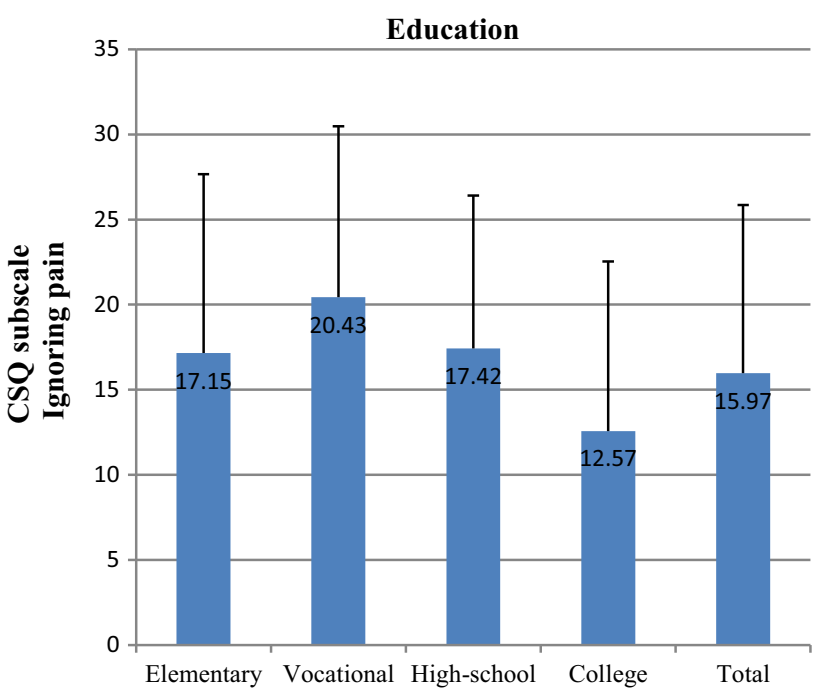

Fig. 8 CSQ scores (ignoring pain) in breast cancer patients vs education

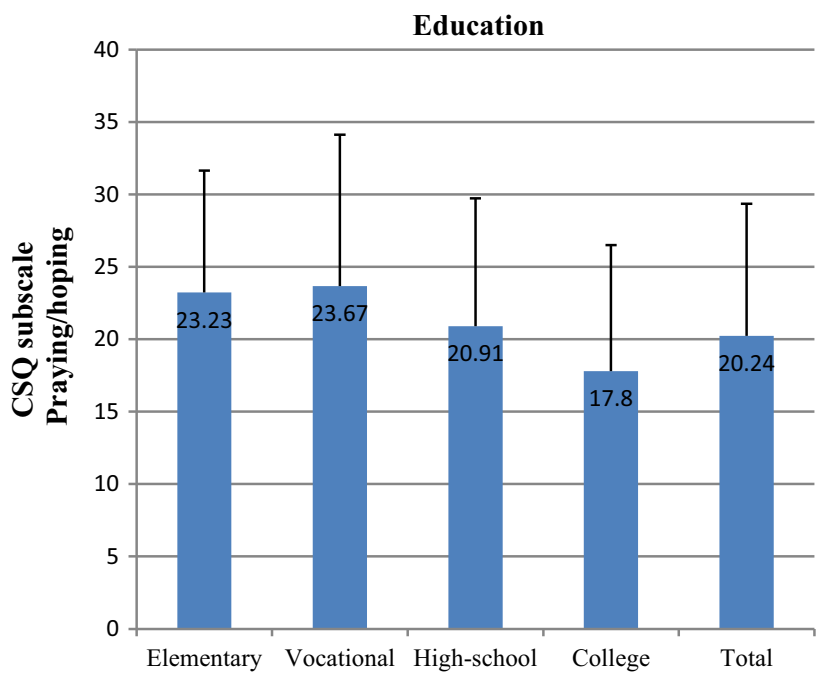

Fig. 9 CSQ scores (praying/hoping) in breast cancer patients vs education

(mean $=21.81)$, and the lowest score in the catastrophizing subscale (mean score $=10.60$ ) (Fig. 5).

We found out that the most important socioeconomic variables that affected test scores were education and netincome-per-household-member. We observed significant differences within the "education" variable in nearly all subscales: diverting attention $(p=0.002)$ (Fig. 6), reinterpreting pain sensations $(p=0.006)$ (Fig. 7), ignoring pain $(p=0.001)$ (Fig. 8), praying/hoping $(p=0.041)$ (Fig. 9), and increased behavioral activity $(p=0.015)$ (Fig. 10). We registered a noticeable drop in the mean scores along an increase in education, but the real difference we could see 


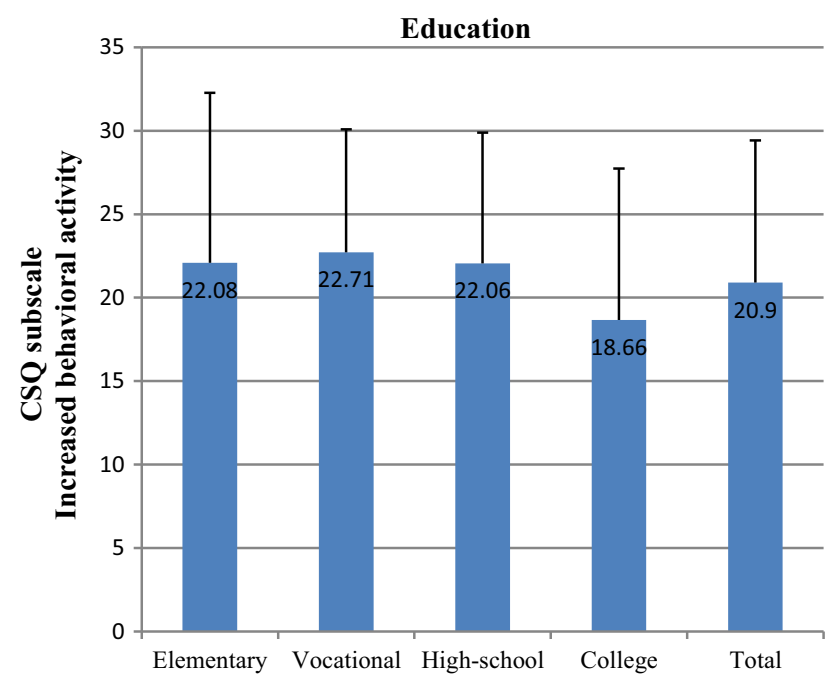

Fig. 10 CSQ scores (increased behavioral activity) in breast cancer patients vs education

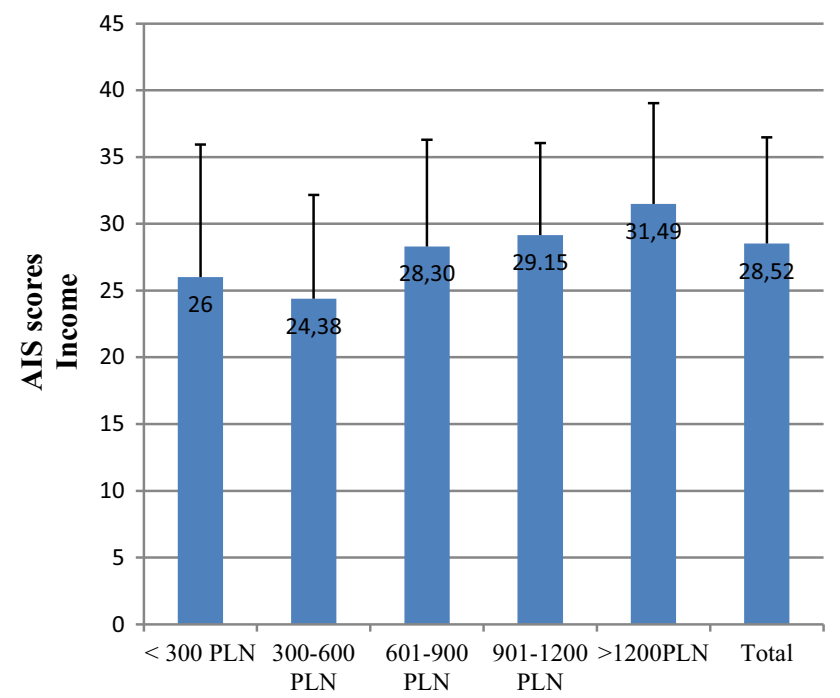

Fig. 11 AIS scores in breast cancer patients vs net income per household member

only between vocational- and high-school graduates and college graduates. The groups treated individual strategies similarly and only in the reinterpreting pain sensations subscale the mean scores of respondents were lower.

Income-per-household-member differentiated the scores obtained in the following subscales: diverting attention $(p=0.011)$, reinterpreting pain sensations $(p=0.011)$, and praying/hoping ( $p=0.001)$. The effect of the above strategies was inversely correlated with income. A similar correlation was observed in the case of the other subscales, but the differences recorded were not statistically significant.

The size of the place of residence and professional status of the study subjects had no effect on the strategies of

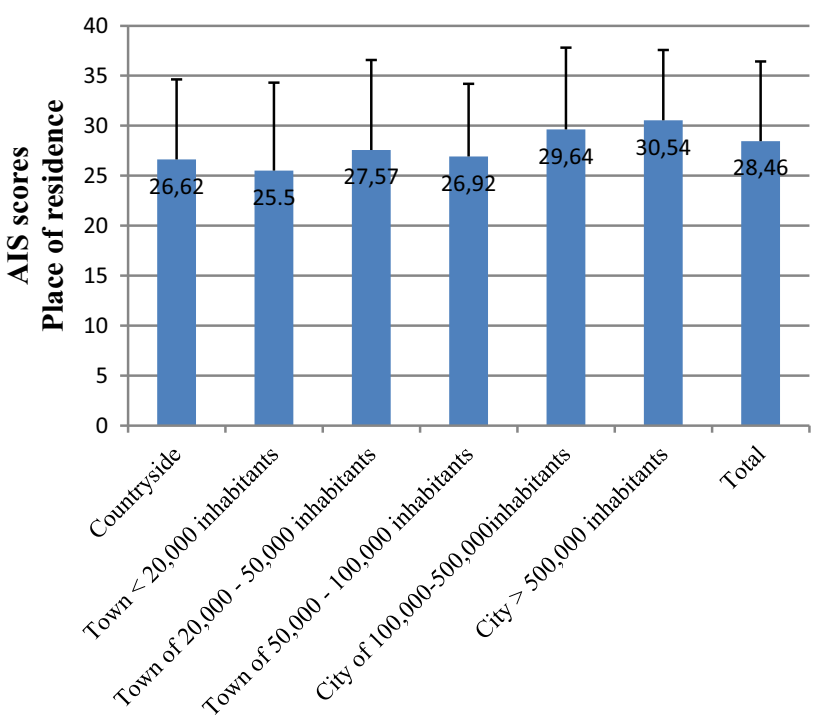

Fig. 12 AIS scores in breast cancer patients vs place of residents

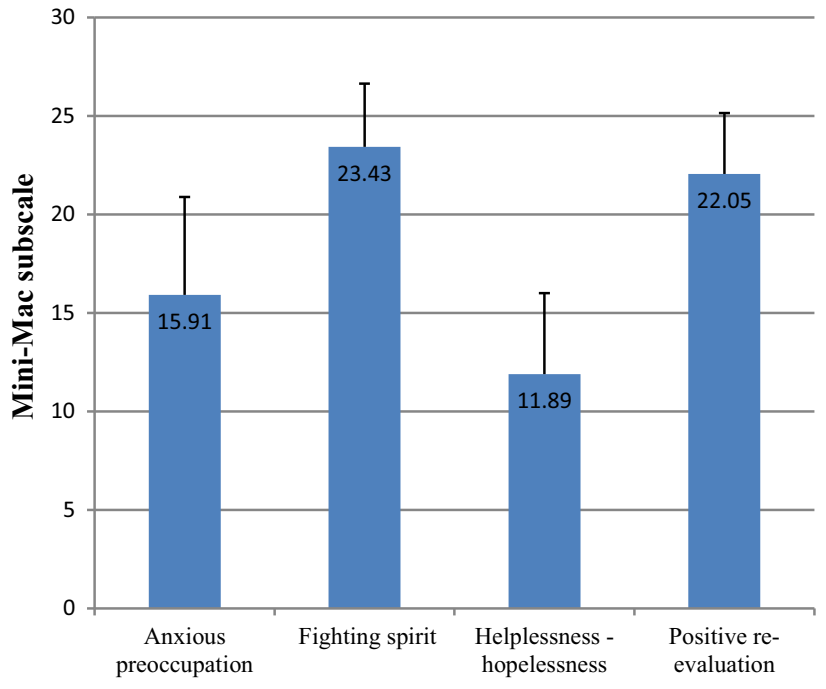

Fig. 13 Mini-MAC test scores in breast cancer patients

coping with pain. In the first case, we recorded significant differences between individual income groups only with regard to the ignoring pain subscale $(p=0.042)$. No significant differences were registered in any of the subscales between those in employment and the pensioners.

\section{Disease acceptance}

The Acceptance of Illness Scale (AIS), a tool for measuring disease acceptance, is composed of eight statements forming a single scale. The total score of every respondent may be between 8 and 40. The lower the score, the more intense the negative reactions and emotions related to disease and hence the lower acceptance. The higher the 
score, the better the adjustment to illness and the lower mental discomfort.

The mean test score for breast cancer patients was 28.45 and the standard deviation was 7.98. The major economic factor that differentiated the results was income $(p=0.01)$. We could see a linear correlation between the rise in the net income-per-household-member and the AIS score. The scores ranged from 24.38 in low-income respondents to 31.49 in high-income patients (Fig. 11).

We detected a similar tendency with regard to the place of residence $(p=0.035)$. Patients living in large cities had higher scores and hence presented better adjustment to disease (Fig. 12).

AIS test scores were not differentiated by education or professional status.

\section{Mental adjustment to disease}

The mini-Mental Adjustment to Cancer (mini-MAC) scale measures four methods of coping with disease: anxious preoccupation, fighting spirit, helplessness-hopelessness, and positive re-evaluation. While the two former methods are a part of the passive (destructive) style of coping, the latter two refer to the active (constructive) way of managing disease $[11,12]$.

Breast cancer patients had the highest mini-MAC scores in the fighting spirit (23.43) and positive re-evaluation (22.05) subscales, and the lowest in the helplessnesshopelessness subscale (11.89) (Fig. 13).

Differences between individual socioeconomic groups were minor. The only statistically significant difference we recorded was for the professional status in the positive reevaluation subscale $(p=0.008)$.

Chemotherapy in the preceding 12 months divided the patients into two categories: respondents who were administered chemotherapy obtained higher results in the anxious preoccupation and helplessness-hopelessness subscales, as opposed to the fighting spirit and positive reevaluation categories, where they obtained lower scores. Nevertheless, the observed differences were significant only with regard to the anxious preoccupation subscale: 17.25 in patients who were undergoing chemotherapy and 15.43 in those who were not $(p=0.032)$.

\section{Discussion}

The International Association for the Study of Pain (ISAP) defines pain as an unpleasant experience accompanying and existing or potential tissue risk, and in some cases, also real tissue damage [13]. More than a half of cancer patients report pain [14]. However, pain therapy may be highly difficult owing to its subjectivity and the fact that not only pain intensity but also reaction to painkillers may vary from patient to patient [15].

Many studies [16] demonstrate that the locus of pain control depends on the level of disease acceptance. For instance, breast or ovarian cancer patients who demonstrated low cancer acceptance had little faith in the internal control of pain, while at the same time they attributed a great role in pain management to powerful others (doctors). Moreover, in the study group the highest scores we noted in BPCQ were in the beliefs that doctors controlled pain. The patients attributed the lowest value to internal factors. Similarly to studies with other patient groups, patients often stress that most important in pain management are doctors $[17,18]$.

Patients adopt various strategies in an attempt to reduce pain [19]. In our study, the patients valued coping selfstatements and increased behavioral activity the most, and catastrophizing and reinterpreting pain sensations the least. Rosenstiel and Keefe, who analyzed chronically ill patients, arrived at similar conclusions [9] and so did Juczyński [20].

As already indicated in the study, the most important socioeconomic factors according to a breast cancer patient when selecting a coping strategy are education and income. The correlation between a chosen strategy and education is also demonstrated by Andruszkiewicz et al. [21], who examined a group of patients suffering from osteoarthritis of the hip. Many researchers reckon that praying and catastrophizing, the strategies indicated mostly by elementary-, vocational- and high-school graduates, worsen the general health condition and magnify the feeling of anxiety $[20,22$, 23]. The World Bank data also suggest that there is a correlation between the variables recorded in our study and population's health. According to the idea of the World Bank, health as a function of wealth and education of the society is a form of capital to be accumulated. The wealthier and more educated the society, the higher the health status of its citizens. On the other hand, a healthier society may contribute to faster economic growth of a country [24].

Breast cancer patients exhibit a relatively high level of disease acceptance (mean $=28.45$ ) when compared to other patient groups. Juczyński [25], who conducted studied in various patient groups, concluded similarly; he demonstrated that breast and uterine cancer patients showed a much higher level of acceptance of illness (mean score $=28.13)$ than diabetic patients $(24.81)$, males post myocardial infarction (22.14), males with chronic pain (18.46), and females diagnosed with migraine (24.23). Felton et al. [26], who studied chronically ill patients, and Wiraszka and Lelonek [27], who analyzed leukemia patients, also recorded lower scores (28.08 in the case of the former). Many authors indicate that higher disease 
acceptance leads to greater motivation to fight disease and better health management [28-30].

Breast cancer patients in our study presented an active style of coping with illness, which is an important element affecting longer survival and better quality of life [31, 32]. The study group had the highest score in the mini-MAC test in the positive re-evaluation (22.05) subscale, and the lowest in the helplessness-hopelessness one (11.89). Although our score recorded in the anxious preoccupation subscale was relatively low (15.91), that of mammary cancer patients in the study by Juczyński was 20.10 [12]. Furthermore, we demonstrated that the mean score of the constructive style of coping with disease was 45.48 and of the destructive one, 27.80, whereas Juczyński reports 40.30 and 35.80 , respectively.

Kozak, who analyzed a group of females with cancers of the reproductive system, reported results that are comparable with ours. When compared to gastric, pancreatic, colorectal or prostate carcinoma, her group scored highest in the fighting spirit strategy (23.95) and lowest in the hopelessness-helplessness method [33]. Szczepańska-Gieracha et al. [34] also point out the advantage of breast cancer patients' constructive coping strategies over other groups.

Malicka et al. draw attention to the effect of physical activity on one's attitude to disease. On the basis of a study conducted in women post breast cancer treatment, they concluded that patients who participated in at least 5 different types of activities per week displayed higher results in the fighting spirit category. Especially important were tours and dancing, which improved mini-MAC test scores in the areas of positive re-evaluation and the constructive coping style [35]. Such correlations were further confirmed by other researchers, amongst them Lueboonthavatchai [36] and Pinto et al. [37].

What is more, numerous studies demonstrate that adopted strategies of coping with disease differ with regard to time from diagnosis and treatment stage [33, 38, 39]. For instance, in the study by Szczepańska-Gieracha et al. carried out in breast or reproductive organ cancer outpatients, the mean fighting spirit score was 24.1; the score of patients after treatment was 11.1. Similarly, the positive reevaluation strategy results tend to decrease as the time from diagnosis increases. The helplessness and anxious preoccupation strategies remained stable regardless of the period of time after diagnosis [35].

\section{Conclusions}

1. Breast cancer patients believe that most important in pain management are doctors, and the least important to be the internal factors.
2. Of all strategies of coping with pain, the highest mean score is recorded in the positive coping self-statements section and the lowest in the catastrophizing subscale.

3. The level of disease acceptance depends on breast cancer patients' income. The higher the income, the more accepted the disease.

4. With regard to mental adjustment to disease, the top scores are reported in the fighting spirit and positive reevaluation subscales.

5. The main socioeconomic variables which differentiate the scores obtained in individual tests used in our research are education and net income-per-householdmember.

Acknowledgment We would like to express our gratitude to the President of the Center of Oncology, the M. Skłodowska-Curie Institute in Warsaw, for permission to conduct the study.

Conflict of interest The authors declare that they have no conflict of interest.

Open Access This article is distributed under the terms of the Creative Commons Attribution 4.0 International License (http:// creativecommons.org/licenses/by/4.0/), which permits unrestricted use, distribution, and reproduction in any medium, provided you give appropriate credit to the original author(s) and the source, provide a link to the Creative Commons license, and indicate if changes were made.

\section{References}

1. WHO, Breast cancer: prevention and control. http://www.who. int/cancer/detection/breastcancer/en/index1.html. Accessed 17 Nov 2014.

2. Didkowska J, Wojciechowska U. Nowotwory piersi w Polsce i Europie-populacyjny punkt widzenia. J Oncol. 2013;2(63): $111-8$.

3. Deptała A, Frączek M. Rak piersi. Rozdział w książce Podstawy diagnostyki i terapii nowotworów. In: Frączek M, editor. AlfaMedica Press, Bielsko-Biała; 2008. p. 158-164.

4. Didkowska J, Epidemiologia nowotworów złośliwych piersi w Polsce. http://www.korektorzdrowia.pl/wp-content/uploads/5.joanna-didkowska.pdf. Accessed 25 Sept 2014.

5. Polskie Towarzystwo Onkologiczne, Strategia walki z rakiem w Polsce 2015-2024. http://www.puo.pl/resources/files/Strategia_ Walki_z_Rakiem_W_Polsce_2015_2024.pdf. Accessed 17 Nov 2014.

6. Nowcki A, Kwasińska E, Rzepka K. Wpływ choroby na życie emocjonalne kobiet po operacji raka piersi zrzeszonych w klubach „Amazonka”. Ann Acad Med Stetin. 2009;55(3):81-5.

7. Barnaś E, Skręt A, Skręt-Magierło J. Jakość życia kobiet z choroba nowotworowa piersi. Prz Menopauzalny. 2009;1:15-9.

8. Skevington SM. A standardised scale to measure beliefs about controlling pain (BPCQ): a preliminary study. Psychol Health. 1990;4:221-32.

9. Rosenstiel AK, Keefe FJ. The use of cognitive doping strategies in chronic low back pain patients: relationship to patient characteristics and current adjustment. Pain. 1983;17:33-44. 
10. Juczyński J. Narzędzia pomiaru w promocji i psychologii zdrowia. Warszawa: Pracownia testów psychologicznych; 2009. p. 159.

11. Watson M, Law M, Santos M, Greer S, Baruch J, Bliss J. The Mini-MAC: further development of the Mental Adjustment to Cancer Scale. J Psychol Oncol. 1994;12(3):33-46.

12. Juczyński Z. Narzędzia pomiaru w promocji i psychologii zdrowia. Warszawa: Pracownia Testów Psychologicznych Polskiego Towarzystwa Psychologicznego; 2001. p. 167-74.

13. International Association for the Study of Pain, IASP Taxonomy (term: pain). http://www.iasp-pain.org/Education/Content.aspx?I temNumber $=1698 \&$ navItemNumber $=576 \#$ Pain. Accessed 18 Nov 2014.

14. Nersesyan H, Slavin KV. Current approach to cancer pain management: availability and implications of different treatment options. Ther Clin Risk Manag. 2000;3(3):381.

15. Noble B, Clark D, Meldrum M, et al. The measurement of pain. J Pain Symptom Manage. 2005;29(1):14-21.

16. Juczyński Z. Psychologiczne wyznaczniki przystosowania się do choroby nowotworowej. Psychoonkologia. 1997;1:1-10.

17. Wiśniewska A, Szewczyk MT, Cwajda-Białasik J, et al. Przekonania na temat kontroli bólu u chorych z przewlekłym niedokrwieniem kończyn dolnych. Pielęgniarstwo Chirurgiczne i Angiologiczne. 2009;3:113-21.

18. Misterska E, Jankowski R, Głowacki M. Chronic pain coping styles in patients with herniated lumbar discs and coexisting spondylotic changes treated surgically: considering clinical pain characteristics, degenerative changes, disability, mood disturbances, and beliefs about pain control. Med Sci Monit. 2013;19:1211-20.

19. Suchocka L. Psychologia bólu. Warszawa: Wydawnictwo Difin, Centrum Doradztwa i Informacji Difin Sp. z o.o.; 2008.

20. Juczyński Z. Spostrzegana kontrola a strategie radzenia sobie z przewlekłym bólem. Sztuka Leczenia. 2001;VII(2):9-16.

21. Andruszkiewicz A, Wróbel B, Marzec A, Kocięcka A. Strategie radzenia sobie $\mathrm{z}$ bólem u pacjentów ze zmianami zwyrodnieniowymi stawu biodrowego. Probl Piel. 2008;16(3):237-40.

22. McCracken L, Eccleston Ch. A comparison of the relative of coping and acceptance-based measures in a sample of chronic pain sufferers. Eur J Pain. 2006;10:23-9.

23. Merlijn VP, Hunfeld JA, van der Wonden JC. Factors related to the quality of life in adolescents with chronic pain. Clin J Pain. 2006;22:306-15.

24. European Observatory on Health Systems and Policies Series, Health Systems, Health, Wealth and Societal Well-being. Assessing the case for investing in health systems. In: Figueras J, McKee M, editors. New York: Open University Press; 2012.
25. Juczyński Z. Narzędzia pomiaru w promocji i psychologii zdrowia. Warszawa: Pracownia Testów Psychologicznych Polskiego Towarzystwa Psychologicznego; 2001. p. 164.

26. Felton BJ, Revenson TA, Hinrichsen GA. Stress and coping in the explanation of psychological adjustment among chronically ill adults. Soc Sci Med. 1984;18:889-98.

27. Wiraszka G, Lelonek B. Funkcjonowanie chorego z białaczkạ a akceptacja choroby nowotworowej. Studi Med. 2008;10:21-6.

28. Harrison T, Stuifbergen A, Adachi E, Becker H. Marriage, impairment, and acceptance in persons with multiple sclerosis. West J Nurs Res. 2004;26(3):266-85.

29. Stuifbergen AK, Seraphine A, Roberts G. An explanatory model of health promotion and quality of life in chronic disabling conditions. Nurs Res. 2000;49(3):122-9.

30. Martin LG. Adjusting to type 2 diabetes: the impact of illness cognitions on self management behavior and biological outcomes. Dissertation Abstracts International: Section B: The Sciences and Engineering 2012;72(9-B):5594.

31. Pettingale KW. Doping and cancer prognosis. J Psychosom Res. 1984;28:363-4.

32. Bussel V, Naus M. A longitudinal investigation of coping and posttraumatic growth in breast cancer survivors. J Psychosoc Oncol. 2010;28:61-78.

33. Kozak G. Zróżnicowanie strategii radzenia sobie z nowotworem chorych w przebiegu wybranych nowotworów złośliwych. Anestezjologia i Ratownictwo. 2012;6:162-70.

34. Szczepańska-Gieracha J, Malicka I, Rymaszewska J, Woźniewski M. Przystosowanie psychologiczne kobiet bezpośrednio po operacji onkologicznej i po zakończeniu leczenia. Współcz Onkol. 2010;14(6):403-10.

35. Malicka I, Szczepańska-Gieracha J, Jankowska E, Woźniewski M, Rymaszewska J. Aktywność fizyczna, satysfakcja z życia oraz przystosowanie psychiczne do choroby nowotworowej u kobiet po leczeniu raka piersi. Współcz Onkol. 2011;15(3):180-5.

36. Lueboonthavatchai P. Prevalence and psychosocial factors of anxiety and depression in breast cancer patients. J Med Assoc Thai. 2007;90(10):2164-74.

37. Pinto B, Trunzo J, Reiss P, Shiu S-Y. Exercise participation after diagnosis of breast cancer: trends and effects on mood and quality of life. Psychooncology. 2002;11:389-400.

38. Taylor S. Przystosowanie do zagrażających wydarzeń. Now Psychol. 1984;6:15-37.

39. Sears SR, Stanton AL, Danoff-Burg S. The yellow brick road and the emerald city: benefit finding, positive reappraisal, and posttraumatic growth in women with early stage breast cancer. Health Psychol. 2003;22:487-97. 